\title{
PENGARUH USIA TERHADAP KUALITAS HIDUP PASIEN MYOCARDIAL INFACTION
}

\author{
Tophan Heri Wibowo ${ }^{1}$ \\ ${ }^{1}$ Program Studi S1 Keperawatan Universitas Harapan Bangsa \\ bowo_4@yahoo.com
}

\begin{abstract}
ABSTRAK
Pasien dengan Myocardial infarction dan stroke adalah kelompok risiko tertinggi untuk kejadian koroner dan gangguan serebral. Myocardial infarction mempengaruhi kesehatan fisik, psikososial, spiritual dan mempengaruhi kualitas hidup secara keseluruhan. Penelitian ini bertujuan untuk mengetahui pengaruh usia terhadap kualitas hidup pasien Myocardial infarction. Penelitian ini menggunakan desain deskriptif korelasional dengan pendekatan cross sectional. Alat yang digunakan dalam penelitian ini adalah kuesioner yang diadaptasi dari instrumen MacNew Quality of Life After Myocardial Infarction (MacNew QLMI) questionnaire untuk mengukur kualitas hidup pasien Myocardial Infarction. Hasil penelitian ini diperoleh usia pertengahan sebanyak 66,7 \%. Kualitas hidup untuk domain fisik adalah mean=4,51. Dari hasil uji Mann Whitney diperoleh domain emosional $\mathrm{p}=0,995(\mathrm{p}<0,05)$, domain fisik $\mathrm{p}=0,624(\mathrm{p}<0,05)$, domain sosial $\mathrm{p}=0,191 \quad(\mathrm{p}<0,05)$ hal ini menunjukkan bahwa usia tidak mempengaruhi kualitas hidup pasien Myocardial infarction.
\end{abstract}

Kata kunci: Usia, Kualitas hidup, Myocardial Infarction

\section{ABSTRACT}

Patients with previous myocardial infarction and stroke are the highest risk group for further coronary and cerebral events. myocardial infarction alters physical, psychosocial, spiritual wellbeing and adversely affects overall quality of life This study aimed to determine the effect of age and the quality of life among myocardial infarction patients. This study utilized descriptive correlational research with cross sectional approach. The study utilized set of instruments, an adapted instrument of MacNew Quality of Life After Myocardial Infarction (MacNew QLMI) questionnaire to measure the quality of life myocardial infarction. The results of this study were obtained middle age group were 66,7 \%. Quality of life for physical domain has an average weighted mean of 4.51. the results of the data analysis using the Mann Whitney test were obtained emotional domain $p=0,995$ ( $p<0,05)$, physical domain $p=0,624(p<0,05)$, social domain $p=0,191$ $(p<0,05)$. It means that the age does not influence the quality of life of patients with Myocardial Infarction.

Keywords: Age, Quality of Life, Myocardial infarction

\section{PENDAHULUAN}

Pasien setelah diagnosis

Myocardial Infarction harus hidup

dengan konsekuensi, seperti sesak napas, terutama pada malam hari, dilaporkan sebagai memiliki efek yang paling negatif karena menimbulkan

kecemasan, takut mati dan gangguan tidur serta mengakibatkan kelemahan fisik dan emosional (Roebuck \& Thompson, 2001 cit Panthee, Kritpracha \& Chinnawong, 2011). 
Ada 32.400.000 kasus Myocardial Infarction (MI) dan stroke di seluruh dunia setiap tahun. Pasien dengan MI dan stroke adalah kelompok risiko tertinggi untuk kejadian penyakit jantung koroner dan gangguan serebral. Pasien MI mengalami peningkatan risiko infark berulang dan memiliki tingkat kematian setiap tahunnya enam kali lebih tinggi daripada orang yang berusia sama yang tidak memiliki penyakit MI (WHO, 2015). Data dari Survei Kesehatan Nasional Indonesia, yang dilakukan oleh Departemen Kesehatan, Republik Indonesia, menunjukkan bahwa penyakit kardiovaskular adalah penyebab utama kematian dari penyakit non infeksi di Indonesia. Survey pada 2013, berdasarkan diagnosis/ gejala penyakit kardiovaskular sekitar 2.650.340 orang (Depkes RI, 2014).

\section{Myocardial}

Infarction mempengaruhi kesehatan fisik, psikososial, spiritual dan mempengaruhi kualitas hidup secara keseluruhan. Kualitas hidup merupakan komponen yang penting bagi pasien MI (Panthee et al., 2011). Kualitas hidup adalah refleksi dari kesehatan mental dan fisik seseorang dalam kehidupan sehari-hari
(Nicolson, 2003). Penyakit jantung berkontribusi pada penurunan besar kualitas hidup di semua dimensi, baik fisik maupun mental (Sawicka, Jurkowska, Bachórzewska-Gajewska, \& Dobrzycki, 2008). Dengan demikian, bagaimana individu mengatasi penyakit ini sangat penting untuk fungsi dan kualitas hidup.

Penyakit jantung seperti MI merupakan penyakit kompleks yang menuntut koping pasien untuk meningkatkan kualitas hidup. (Stefanek, McDonald, \& Hess, 2005). Berbagai penyakit termasuk infark miokard salah satu faktor resikonya adalah penuaan. Usia yang meningkat dapat menyebabkan kondisi yang buruk dari pembuluh darah yang menyebabkan aterosklerosis. Seseorang yang sudah lanjut usia menghadapi permasalahan kondisi fisik yang lemah dan berbagai penyakit yang mengancam sehingga dapat mempengaruhi kualitas hidupnya (Bowman, Watson \& beasty, 2006).

Hasil penelitian dari Norekval et al (2007) bahwa Beban MI secara signifikan mempengaruhi kesehatan fisik perempuan lanjut usia. Usia ratarata pasien infark miokard berusia 72 tahun atau kisaran yang lebih tua. 
Hasil penelitian dari Kristofferzon (2005) dengan menggunakan kuesioner SF-36 Health Survey (health-realated quality of life) dan the Quality of Life index-Cardiac version (quality of Life) bahwa kualitas hidup erat kaitannya dengan usia dimana usia lanjut berkaitan dengan penurunan fungsi fisiologis.

Peneliti ketika praktik dirumah sakit pernah melakukan pengamatan pada pasien yang didiagnosis dengan penyakit infark miokard akut dan stroke sering menghadapi berbagai kesulitan yang dibawa oleh penyakit seperti keterbatasan fisik, beban keuangan, kehidupan yang penuh stres, dan Sebagian besar pasien yang mengalami penyakit infark miokard dan stroke adalah lansia.

Dengan demikian, peneliti termotivasi untuk melakukan penelitian ini untuk membuktikan bahwa usia berpengaruh terhadap kejadian Miocardial Infarction. Penelitian ini dilakukan untuk mengetahui pengaruh usia dengan kualitas hidup pasien Miocardial Infarction. seiring

Penelitian ini bertujuan untuk mengetahui pengaruh umur terhadap kualitas hidup pasien Myocardial infarction. Perbedaan penelitian ini dengan penelitian sebelumnya adalah kuesioner yang digunakan spesifik untuk mengukur kualitas hidup pasien Miocardial Infarction yaitu menggunakan kuesioner MacNew QLMI questionnaire sedangkan penelitian lain ada yang menggunakan kuesioner SF-36 Health Survey (healthrealated quality of life). Penelitian ini juga menjabarkan pengaruh usia dengan kualitas hidup berdasarkan domain pada pasien Miocardial Infarction.

\section{METODE PENELITIAN}

Penelitian ini menggunakan desain deskriptif korelasional dengan pendekatan cross sectional. Alat yang digunakan dalam penelitian ini adalah kuesioner yang diadaptasi dari instrumen MacNew Quality of Life After Myocardial Infarction (MacNew QLMI) questionnaire untuk mengukur kualitas hidup pasien Myocardial Infarction.

Pengambilan sampel pada penelitian ini menggunakan teknik purposive sampling. Responden adalah pasien yang memiliki karakteristik sebagai berikut; pasien Muslim, didiagnosis Myocardial Infarction, bersedia untuk berpartisipasi dalam 
penelitian ini. Responden dikeluarkan jika mereka memiliki gangguan mental yang berat atau cacat lainnya. Responden penelitian terdiri dari 69 pasien dengan Myocardial Infarction di Banjarnegara, Jawa Tengah, Indonesia dari total populasi sejumlah 69 pasien. Penelitian ini diambil dalam rentang waktu bulan april - Agustus 2015.

Data dianalisis statistik Mann Whitney digunakan untuk menentukan apakah ada perbedaan yang signifikan secara statistik antara dua kelompok variabel independen.

\section{HASIL DAN PEMBAHASAN}

Bab ini menyajikan, menganalisis dan menafsirkan temuan berdasarkan masalah-masalah khusus penelitian. Pada penelitian ini peneliti ingin mengetahui pengaruh umur terhadap kualitas hidup pasien MI.

Myocardial Infarction umumnya ditemukan pada pasien usia pertengahan. Penuaan berisiko terhadap berbagai penyakit termasuk MI. Usia yg meningkat dapat menyebabkan kondisi yang buruk dari pembuluh darah yang menyebabkan aterosklerosis, masalah kesehatan umum di antara pasien. Hasil penelitian ini didukung oleh Norekval et al (2007). Beban MI secara signifikan dipengaruhi kesehatan fisik perempuan lanjut usia. Usia rata-rata pasien MI berusia 72 tahun atau kisaran yang lebih tua.

Tabel 1. Distribusi profil demografis berdasarkan usia

\begin{tabular}{lcc}
\hline \multicolumn{1}{c}{ Profil demografis } & Frekuensi & Persentase \\
\hline Usia & & \\
35-64 & 46 & 66,7 \\
65 dan di atas & 23 & 33.3 \\
\hline Total & 69 & 100 \\
\hline
\end{tabular}

Tabel 2. Domain Kualitas hidup pasien Myocardial Infarction

\begin{tabular}{ccc}
\hline Domain & Mean & Interpretasi \\
\hline Emosional & 4,39 & sedang \\
\hline Fisik & 4,51 & baik \\
\hline Sosial & 4,43 & sedang \\
\hline
\end{tabular}

Berdasarkan data kualitas hidup pasien Myocardial Infarction dari 3 
domain yaitu emosional, fisik dan sosial menunjukkan bahwa kualitas hidup pasien dengan infark miokard dalam domain fisik nilai rata-rata mean 4,51 atau pasien kebanyakan baik dengan domain fisik mereka.

Kualitas hidup pasien dengan Myocardial Infarction dalam domain emosional masuk kategori sedang. Ini berarti bahwa pasien dengan Myocardial Infarction dapat memiliki kualitas hidup yang baik di satu sisi dan kualitas hidup yang buruk di sisi lain.
Hasil dari penelitian ini adalah sama dengan Kelainan fungsi kardiovaskular sangat terkait dengan Boersma et al (2005). Menurut mereka, hambatan mengganggu pencapaian tujuan hidup ini terkait dengan tingkat stres yang lebih tinggi dan kualitas kesehatan yang lebih rendah. Kelainan fungsi kardiovaskuler sangat terkait degan fungsi psikososial, gaya hidup dan perilaku pola pasien (Mierzyńska, et al., 2010).

Tabel 3. Pengaruh usia terhadap kualitas hidup pasien Myocardial Infarction

\begin{tabular}{clccc}
\hline \multicolumn{2}{c}{$\begin{array}{c}\text { Kualitas hidup Myocardial } \\
\text { Infarction }\end{array}$} & p value & Deskripsi & Ket \\
\hline \multirow{3}{*}{ Usia } & domain emosional & 0,995 & Tidak signifikan & Ho diterima \\
\cline { 2 - 5 } & domain fisik & 0,624 & Tidak signifikan & Ho diterima \\
\cline { 2 - 5 } & domain sosial & 0,191 & Tidak signifikan & Ho diterima \\
\hline
\end{tabular}

Berdasarkan hasil pada tabel 3, perbedaan kualitas hidup didomain emosional, fisik, dan sosial berdasarkan kelompok umur dengan dihitung nilai $\mathrm{p}$ dari 0,995, 0,624, 0,191 ( $\mathrm{p}<0,05)$ maka kelompok usia tidak mempengaruhi kualitas hidup Myocardial Infarction dari domain emosional, fisik, dan sosial. Semakin tua orang tersebut tidak membuat kualitas hidup yang lebih buruk. Kualitas hidup tidak hanya tergantung pada usia seseorang. Dukungan keluarga, pikiran dan perilaku memiliki peran penting untuk mendapatkan kualitas hidup yang baik. Faktor keuangan dan hubungan dengan keluarga dan masyarakat juga dapat meningkatkan kualitas hidup. Temuan ini mirip dengan studi oleh Ghasemi et al. (2014) menemukan bahwa tidak ada hubungan yang signifikan antara QOL dan usia, pekerjaan dan komorbiditas. 
Berdasarkan temuan, peserta memiliki tingkat rata-rata keseluruhan kualitas hidup.

Dukungan keluarga dan perilaku berperan penting terhadap kualitas hidup yang baik meskipun lanjut usia. Pikiran juga berperan penting terhadap kualitas hidup sehingga walaupun sudah lanjut usia tetapi kualitas hidup tetap baik

\section{KESIMPULAN DAN SARAN}

Berdasarkan hasil penelitian dapat disimpulkan bahwa sebagian besar usia pasien Myocardial Infarction adalah usia pertengahan. Mayoritas responden memiliki kualitas hidup yang sedang dalam domain emosional dan sosial sedangkan domain fisik masuk kategori baik, sehingga mengakibatkan kualitas hidup yang tinggi di antara pasien MI. Tidak ada pengaruh yang signifikan antara usia dengan domain emosional, fisik dan sosial kualitas hidup pasien MI.

\section{DAFTAR PUSTAKA}

Boersma, S. N., Maes, S. \& Joekes, K. (2005). Goal disturbance in relation to anxiety, depression, and health-related quality of life after myocardial infarction. Qual Life Res, 14, 2265-2275.
Bowman, G., Watson, R., Beasty, A.T. (2006) Primary Emotions In Patients After Myocardial Infarction, Journal of Advanced Nursing. 53(6): 636-645.

Depkes RI (2014). Situasi kesehatan Jantung. Jakarta: pusat data dan informasi kementrian kesehatan.

Ghasemi, E., Aliha, J., Bastani F., Haghani, H. \& Samiei, N. (2014). Quality of life in women with coronary artery disease. Iran Red Crescent Med J., 16(7). doi: 10.5812/ircmj.10188.

Kristofferzon, M. L., Lofmark, R. \& Carlsson M. (2005). Coping, social support and quality of life over time after myocardial infarction. $J$ Adv Nurs, 52, 113-124.

Mierzynska, A., Kowalska, M., Stepnowska, M., \& Piotrowicz, R. (2010). Psychological support for patients following myocardial infarction. Cardiology Journal, 17(3), 319324.

Nicolson P. \& Anderson P. (2003). Quality of life, distress and selfesteem: a focus group study of people with chronic bronchitis. Br J Health Psychol, 8, 251-70.

Norekval, T. M., Wahl, A. K., Fridlund, B., Nordrehaug, J. E., WentzelLarsen, $\mathrm{T} \&$ Hanestad, B. R. (2007). Quality of life in female myocardial infarction survivors: A comparative study with a randomly selected general female population cohort. Health 
and Quality of Life Outcomes, 5, 58. doi:10.1186/1477-7525-5-

58.

Panthee, B., Kritpracha, C \& Chinnawong, T. (2011). Correlation between coping strategies and quality of life among myocardial infarction patients in nepal. Nurse Media Journal of Nursing, 1(2), 187194.

Sawicka, J., Jurkowska, G., Bachórzewska-Gajewska, H. \& Dobrzycki, S. (2008). Evaluation of the quality of life and frequency of depressive symptoms in patients with coronary heart disease before planned coronarography. Przegl Kardiodiabet, 3, 23-27.

Stefanek M., McDonald P. G., \& Hess S. A. (2005). Religion, spirituality and cancer: Current status and methodological challenges. Psychooncology, 14, 450-463. doi:10.1002/pon.861.

World Health Organization. (2015). Prevention of Recurrences of Myocardial Infarction and Stroke Study. Retrieved from http://www.who.int/cardiovascul ar_diseases/priorities/secondary_ prevention/country/en/index1.ht $\mathrm{ml}$. 